\title{
Theatre Reviews
}

\section{Richard III. Dir. Paris Erotokritou. Cyprus Theatre Organization, Nicosia, Cyprus.}

\section{Reviewed by Eleni Pilla*}

Richard III, directed by Paris Erotokritou for the Main Stage of the Cyprus Theatrical Organization (THOC) in Nicosia, was fully packed on both evenings that I went to see it. The production offered a unique Shakespeare experience. Being the second longest play in the Shakespearean canon, Richard III is undoubtedly a difficult play to make accessible to an audience with no prior knowledge of Shakespeare's language, the specific play and genre, or British history. The Cypriot audience is familiar with plays such as Othello, with four acts taking place in Cyprus, Hamlet and A Midsummer Night's Dream. Erotokritou's spectacular production was ingenious and captivating, thus rising formidably to the challenge of staging Shakespeare's history play for the first time in Cyprus. The Greek translation that was used for the production was by Nikos Hatzopoulos.

The stage design for Richard III deftly brought the audience close to the characters of the play. A central aisle was constructed in the middle of the auditorium, so that the audience sat on both sides of it, and at the back of the aisle there were also several rows of seats. High walls on the stage opened and shut, in certain instances very quickly, creating a sense of urgency. At one point Richard was right in between the walls as they shut and his walking stick touched the closing wall. The use of light and shadow was particularly astute. Richard appeared in spotlight during parts of his soliloquies. The shadow of Clarence on the wall magnified his stature when his murderers arrived, functioning as an ironic contrast to the diminution he would undergo once murdered.

From the outset, Richard, played by Prokopis Agathocleous, was a very remarkable presence on stage. Richard began the "Now is the winter of our discontent" speech in Greek from the back of the aisle and progressed towards the stage facing the audience. (A similar strategy was employed in

\footnotetext{
* Independent scholar.
} 
Charalambous's 2012 Othello, where Iago made his first entrance from the back of the auditorium, suggesting that one had to watch one's back when Iago was around.) Richard's heinous villainy was at once condemnable but irresistibly attractive. The audience almost ended up being the staunchest supporters of Agathocleous's incandescent Richard. The variety and depth of Richard's characterization was brought to the fore as he manipulated those around him. His charisma radiated, whether he was presented nearly devouring a red rose and leaving petals strewn on the aisle, or drinking from Tyrrell's cocktail glass, puffing from Radcliffe's cigarette, tapping his walking stick on the medals of honor of those whose ambitions he wished to energize. A morbid sense of humour characterized Richard, as it was also crystallized in the image of him bending to determine if the lifeless body of Edward, ready for burial, was alive, when Lady Anne exclaimed "He is alive." This production did not present a simple caricature of villainy, but brought to the foreground Richard's extreme agility and inventiveness. The entire production was marked by a restlessness which forged a sense of immediacy and captivated the audience.

The audience was inevitably sucked into the world of the production. The boundary between the stage world and the auditorium collapsed, as the spectators were not exempt from the danger portrayed on stage and became engaged in the events they witnessed. Richard was not the only one to see ghosts. In one instance black sinister figures, ghostlike apparitions, appeared in the auditorium hovering over audience members, creating a strong sense of an omnipresent threat and prefiguring doom. When the spectators became aware of their surreptitious presence, they were perplexed about how long they had been lingering around for. I noticed the ominous figure several rows in front of me but was very surprised to find out that there was one right next to me as well!

At the heart of the production was the theme of corruption. At the beginning of the play, amidst thunder, it was announced that it is $2019 \mathrm{AD}$, and a historian asked if the Middle Ages had ended. Underscoring the contemporary resonance of Shakespeare's early modern play, Erotokritou's rendition of Richard III intimated that modern society still lives in the Middle Ages because corruption plagues it. The audience was asked to evaluate critically what happened before them and to oppose corruption actively, as was also indicated immediately before the interval when confetti was thrown in the auditorium and large backcloths were hung up stretching from the second gallery with statements such as "King Richard III of England, Legitimate, Natural

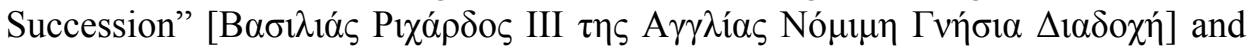

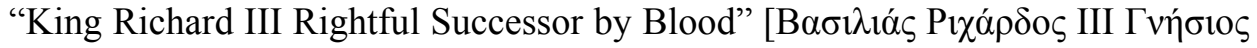
$\Delta \mathrm{i \alpha ́ \delta 0 \chi 0 \varsigma}$ E $\xi$ Aí $\mu \alpha \tau o \zeta]$. Two-sided fliers were thrown into the auditorium, with one side paradoxically celebrating the reign of Richard ("Long Live King

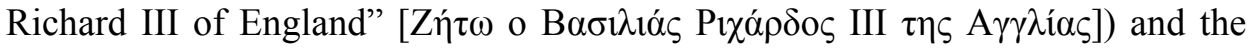
other side urging the audience to "put an end to decadence, disgrace, and 


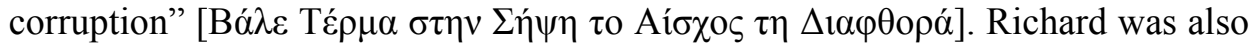
associated with bestiality, in a hilarious and comic way, as a cartoonish sort of wild boar appeared to stand for Richard and his reign. In the Shakespearean play, Queen Margaret describes Richard as an "abortive, rooting hog" (1:3:227). Historically, the boar was Richard's personal heraldic symbol.

The music by Marios Takoushis very effectively enhanced the mood of the play, while also amplifying the action and the psychology of the characters. As Richard was crowned, the very vivid music signalled supreme pompousness, even hilariousness. Discussing the play with a friend who attended the production, she remarked "I can still hear the music." The music and the portrayal of Richard towering above everyone when he climbed and sat on a flight of three steps when crowned functioned as a critique of Richard. He appeared contradictory: an exceptionally strong and alluring villain but also a pretty vain man. The music also made topical allusions to the history of Cyprus. The echo of sirens in certain instances could be evocative of the sirens that were heard on the island in the early morning hours of the 20th of July 1974, the day when the Turkish invasion of Cyprus took place.

Erotokritou's Richard III called attention to the complex relationship between history and theatrical representation, and the extent to which theatrical representation can serve as the mouthpiece for propaganda. A historian at the beginning and at the end of the play directly asked questions such as: "Which methods are used to promote propaganda in the theatre?", "What does historical truth mean?", "How is history written and how is it read?", "Can myth be stronger than historical truth?". Since the historian was silenced by a figure who closed his mouth and dragged him back, the audience was encouraged to ponder on these issues. The character of Richard engaged in a dialogue with his representation in history and the theatre as he asked "Who spoke about disability?". In puzzlement he asked "Shakespeare?" and was informed "author of Richard III."

The deployment of intertextuality concerning the discovery of the remains of Richard III in August 2012 had the effect of creating ambiguity and a multiplicity of meanings. The extensive and detailed display of injuries being inflicted on Richard on stage, while eliciting sympathy towards him, also signalled that one cannot escape punishment for his evildoings. Also, Richard's tormentors were portrayed as not very dissimilar to him. Richard's body was fetishized while an element of piety was attributed to him, and he might even be likened to a tortured saint. Richard's affirmation in the Shakespearean original: "And thus I clothe my naked villainy/With old odd ends stol'n forth of holy writ,/And seem a saint, when most I play the devil" (1:3:335-337) also related to the depiction of Richard on stage. Nearly naked, in white underwear, Richard contradictorily appeared as a bleeding saint, whose naked villainy had been exposed and avenged by the souls of those he had killed. The prolonged display 
of Richard being injured could negotiate issues of political theology. By entailing that sovereignty apart from glory and power involves pain and suffering, the production demonstrated Ernst H. Kantorowicz's concept of the king's two bodies: the body politic and the body natural. The body natural suffered before our eyes. The spectator was overwhelmed with different meanings.

A magnificent production, THOC's Richard III was exemplary in its approach to a difficult Shakespearean play that had never been staged in Cyprus before. This spectacular production was highly acclaimed in Cyprus and, having seen it twice, I have no doubt that it would have won the accolade of the audience in any of the Shakespeare theatres in Stratford-upon-Avon had it been staged there.

\section{WORKS CITED}

Kantorowicz, Ernst H. The King's Two Bodies: A Study in Medieval Political Theology. Princeton: Princeton UP, 1957.

Shakespeare, William. Richard III. The Riverside Shakespeare. $2^{\text {nd }}$ ed. Boston: Houghton Mifflin, 1997.

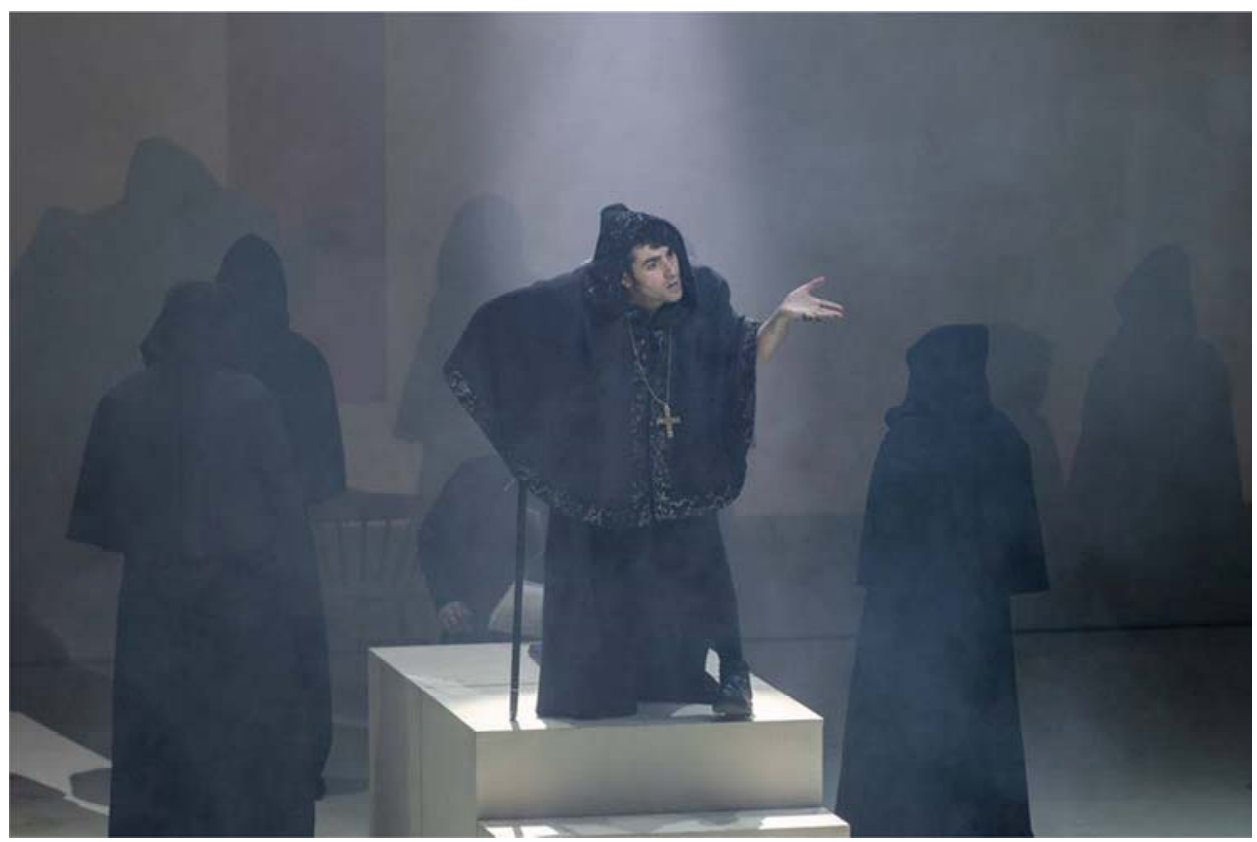

Photograph by Clicks n’ Films 
Othello. Dir. Charis Fragoulis. Art Theatre Karolos Koun, Athens, Greece.

Reviewed by Xenia Georgopoulou*

\section{A Tragicomical Othello with a White Moor and a Basket of Lemons}

The word 'tragicomedy', at least regarding Shakespeare's works, has mostly been used for his romances (Danson 20), a group of plays that culminate in a happy ending after a series of serious events in the lives of most of their major characters. The way I am using the word here, however, is different: Charis Fragoulis's Othello at the Art Theatre Karolos Koun in the Greek capital was enriched with a great deal of comical elements, and nevertheless retained its tragic character.

The addition of comical details here and there definitely made it easier for the audience to watch a two-and-a-half-hour production with no interval. Interestingly, these comical 'amendments' in one of Shakespeare's major tragedies did not seem out of place-with a few exceptions. On the contrary, they even seemed to the point on many occasions.

Brabanzio's hysterical reaction to his daughter's elopement with the Moor in the beginning of the play could well be on the verge of the comical. It seems that the director did not even care if the text was heard properly: Angelos Papadimitriou's Brabanzio lacked in proper enunciation in his panic to locate his daughter and verify Iago's story; however, his hysterical mumbling and his interaction with the audience had exactly the same effect with the text had it been uttered properly. Additions were also made to the original here, such as "My little girl is cheating on me!", as if Desdemona were her father's mistress (Aivaliotou), once more exaggerating on Brabanzio's feelings for his daughter.

And yet Desdemona's portrayal by Fragoulis had something of daddy's baby girl, which was perfectly performed by Sofia Kokkali. Her costume (especially her short skirt, short socks and flat shoes in light colours-a light beige, mostly) and her ponytail alluded to childhood and innocence. Even her hugging and kissing with her husband seemed particularly clumsy (another token of the heroine's lack of experience in such matters), and this clumsiness was underscored by the music (played on a piano by the composer Cornilios Selamsis), which seemed to interact with the couple's entangled bodies.

Cassio (played by the restless Andreas Konstantinou, who took Polaroids throughout the play) also behaved childishly, and was portrayed as Othello's faithful dog, making the longing sounds dogs make when they see their masters etc. He was also given more comical touches here and there, also

\footnotetext{
* National and Kapodistrian University of Athens, Greece.
} 
involving particular linguistic mistakes-as opposed to Andreas Kontopoulos's Iago, who seemed to be his foil in eloquence. Wordplay was also used elsewhere, as in the nicknames chosen by Iago for Cassio or by Roderigo (played by Michalis Titopoulos) for himself. Roderigo's stupidity, already present in the play itself, was stressed even more in this production, with more grotesque and ridiculous behaviour on the part of the character, which was also underlined by the way other characters treated him, as in the moment when he was given a tiny bell to summon the citizens of Venice. Elsewhere the comical references were related to the performance itself, with actors commenting on the problems they encountered while trying to move on the set and among the props etc. (Othello, for example, squeezed himself between the wall and the piano and stumbled on lemons lying on the floor.)

On the other hand, Fragoulis avoided what would probably result in a comical effect: painting black the actor playing Othello. Black actors in Greece are still rather scarce, and Fragoulis chose Giannis Papadopoulos, a white, "blond and blue-eyed" (Aivaliotou) actor to play the Moor. So far, the actors that played the Moor in Greece were painted black. However, this was of little importance, really. The white actor was alluded to as "the Moor", and the spectators just had to use their imagination to paint him black. In any case, Othello is treated like a white man by everyone in the play with the exception of Brabanzio. However, a possible reference to Othello's exotic past was some kind of song he sang in moments of crisis (as, for example, when he is tortured by the thought of Desdemona's infidelity, or when he vows to kill her), which alluded to an Arabic or African background. Apart from Othello's whiteness, another matter that was discussed was his nudity. For some spectators it seemed irrelevant; however, the moment the director chose for that could easily justify it. The Moor started undressing himself when he was persuaded that Desdemona was unfaithful, and while murmuring "Love is gone", and then "Blood, revenge". It seemed that, by taking off his clothes, he removed his identity of husband and lover, to take up the role of the avenger.

In spite of Fragoulis's comical additions, the tragical scenes of the play did not lose their strength. After Desdemona's murder, for example, when Emilia (played by Katerina Louvari-Fassoi) came to seek her mistress at her bedchamber, Othello was seized by a rather comical panic: he held his wife's body trying to figure out how to dispose of it in order to hide it from Emilia, and eventually put it on the piano. However, this did not seem to undermine his tragical act.

An interesting idea in the production was the use of barking and dog behaviour at large. Othello barked at Iago asking for proof; Desdemona barked at Othello to persuade him to take Cassio back; and Cassio, who behaved like Othello's faithful dog from the beginning of the show, as was mentioned above, gave an impressive performance of a dog mourning for his master at the end of the play. 
As for the lemons mentioned in the title of this review (another idea of the director that was present throughout the production), with their golden colour, they represented money on some occasions-without this metaphor being consistent, though. It is of note that they were brought to the stage in the beginning of the production, in a large wire fishing basket, by Roderigo, from whom Iago extracts expensive jewels, supposedly for Desdemona. In the scene where Othello treats Emilia like a bawd, Fragoulis's Moor threw lemons at Desdemona's confidante for her pains. In other cases lemons were used to illustrate the feelings of a character, who bit into them, chewed them and spat them out. Othello, for example, bit hard into lemons when he asked Iago for proof of Desdemona's infidelity or while talking of killing Cassio; Desdemona bit into a lemon while pleading for Cassio; and both the Moor and his wife threw lemons at each other when the former accused the latter of adultery.

Like the lemons, another prop that was on stage almost throughout the show was a fountain that was moved around and was lit in different colours. The fountain was brought on stage to illustrate the tempest that annihilated the Turkish fleet. In other moments, however, it was given different connotations. At some point Desdemona moved the fountain (which was waterless at that particular moment) from one side of the stage to the other; she tried to turn it on, and when the water finally spouted, she exclaimed "I knew I could do it!" with childish satisfaction, which gave the impression of a sexual innuendo. Perhaps it is relevant that, immediately after that, Othello used his hands to form horns on his head, and Desdemona did the same playfully, probably having no clue of what he meant. In the next scene Iago did the same with Emilia after she gave him the handkerchief, which apparently turned him on. The horns here could also symbolize sexual activity; however, Iago also refers to Emilia's supposed adultery in the play, so it might as well signify cuckoldry, as usual. The colours of the light in the fountain could also be seen symbolically: for example, when Iago talked to Roderigo of his plan to ruin Othello, the fountain was green, which is the colour of jealousy, the "green-eyed monster" described by Iago in 3:3:170 (Shakespeare), but also of envy (Biedermann 159).

As for the prop-par-excellence of the play, namely Desdemona's handkerchief, it was also used cleverly, with several handkerchiefs appearing on stage. When Iago put the handkerchief in his pocket, another one appeared in Cassio's hands, and when the latter shared his intention to give it to Bianca (played by Aspassia-Maria Alexiou), another handkerchief appeared in her hands when he put his away. Desdemona was also seen playing with the handkerchief right before Iago and Othello talked about Cassio. Another interesting touch was that Desdemona saw the handkerchief falling, but did not pick it up, and left it there, as if she was accepting the fate that would ensue for her.

The music by Selamsis was played live on stage on the piano throughout the production by the composer himself, who also played secondary parts, like 
the Duke or Montano. The music shifted according to the mood of the scene, and occasionally there was also a kind of dialogue between the pianist and the actors, as in a scene where Cassio drank wine making grotesque noises imitating the sounds Selamsis made on the piano. Elsewhere Cassio spent some time trying to decide on the right music to appease Othello, choosing from a variety of genres played on the piano by the composer.

Until the end of the play, it seemed that the director tried to undermine the dramatic scenes. Right before Othello's suicide, the actor playing Roderigo appeared with a sack on his head with Shakespeare's portrait on, and said (playing the Bard himself) that he had to finish the play somehow, to get the money and buy himself wine. However, Othello's suicide did not become less moving after this parenthesis (which seemed totally irrelevant, given that Othello's ending is far from clumsy or abrupt).

In fact, Othello's suicide was particularly interesting. The protagonist did not use a knife; instead, he used a belt, an accessory that appeared in all (or, at least, most of) the costumes of the production (designed by Maria Panourgia). The Moor also used a belt on other occasions: he used one to strangle Desdemona, and right afterwards he attempted to strangle Iago, too, after realising his part in Desdemona's death. (A belt was also used in other ways during the production; for example, Cassio used one to beat Roderigo, who insulted him.) At the end of the production Othello took all the belts from the characters' costumes, tied them together while delivering his last monologue, and created a kind of rope, which he used to commit suicide.

Fragoulis's feelings about his staging of Othello seemed to correspond to what was seen on stage. The director felt, as he confided to Giorgos Mylonas, "absolutely terrified and absolutely at home" with the play (Mylonas). However, in the interview he gave to Mylonas it was not made clear what exactly he tried to do with the play. The director also tried to get the audience involved in the production by placing his actors among the spectators, with whom they interacted. As Panagiota remarks in the online audience reviews section of Athinorama, "the characters [are] accessible and direct, without undermining the infinite, intact nature of what they talk about". Panagiota adds that the production showed respect to Shakespeare "as a human and not as a god" ("Audience reviews").

It seems that Fragoulis's production was a hate-it-or-love-it staging of Shakespeare's tragedy, which was made obvious by the audience's online reviews in Athinorama, which were divided into two extremes. On the one hand, the director's work was seen as "unacceptably exaggerated and tiring" (Iro), "amateur" (Anneza L., Stamatis), "disappointing", a "pointless adaptation" (stargazer), a "superficial [. . .] dissonance" (Katerina Karamanoli), a "trampling upon the text", an "immoderate parody" (Eleftheria), a "stage mediocrity" (Eleni Anyfanti), a "very bad attempt" (Takis), with Polykarpos seeing in Fragoulis 
a "catastrophic [. . .] arrogance", also traced in the whole group by Eleftheria ("Audience reviews"). On the other hand, the production was regarded as "an interesting approach" (Eva), "very interesting" (Mairi), "excellent" (Despina, Ioanna, Giota), "Subversive, Enjoyable, Refreshing, Amusing, Moving" (Anna). However, Anna admitted that "[i]f you want to watch a classical Shakespeare, you'd better not go there" ("Audience reviews"). Vassilis, another online reviewer of Athinorama, probably describes more accurately than any other the feeling left at the end of the production:

Complete, consistent, with a common code, staging tricks and reversals, absolute communication, a sense of humour, but also hard, provocative, dangerous, strangely offensive. It surely had a world that the actors knew well. You get out of the theatre and think, which is great, but I don't know whether you think positively or negatively... which is also great? ("Audience reviews")

Personally, I would disagree with Stergios Pouleres, who argues that Fragoulis's production of Othello "abolished" Shakespeare. However, I would agree with Anna: it would probably be a bad idea for a spectator who has never seen Othello to start with this one.

\section{WORKS CITED}

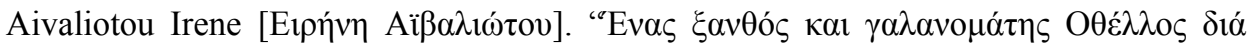

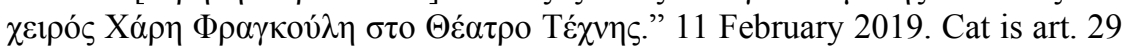
April 2019. <https://www.catisart.gr/enas-xanthos-kai-galanomatis-othellos-diacheiros-chari-fragkoyli-sto-theatro-technis/>

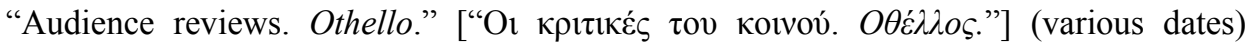

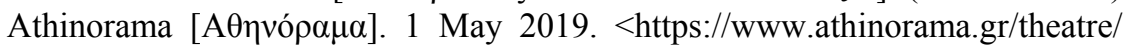
performanceratings.aspx?id $=10063834 \& \mathrm{cp}=1>$

Biedermann, Hans. The Wordsworth Dictionary of Symbolism. Trans. James Hulbert. Ware: Wordswoth, 1996.

Danson, Lawrence. Shakespeare's Dramatic Genres. Oxford Shakespeare Topics. Oxford: Oxford UP, 2000.

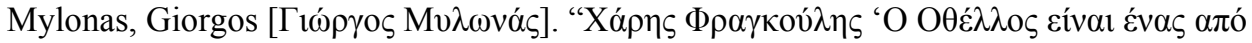
$\varepsilon \mu \alpha \varsigma$ '. 26 February 2019. Huffington Post.gr. 1 May 2019. <https://www. huffingtonpost.gr/entry/chares-fraykoeles-o-othellos-einai-enas-apo-emas_gr_ 5c751ef6e4b0bf1662031327>

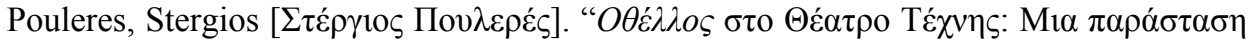

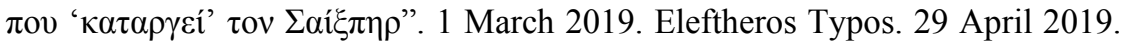
$<$ https://www.eleftherostypos.gr/politismos/376429-othellos-sto-theatro-technismia-parastasi-pou-katargei-ton-shakespeare/>

Shakespeare, William. The Complete Works. Compact edn. Ed. Stanley Wells et al. Oxford: Clarendon, 1997. 


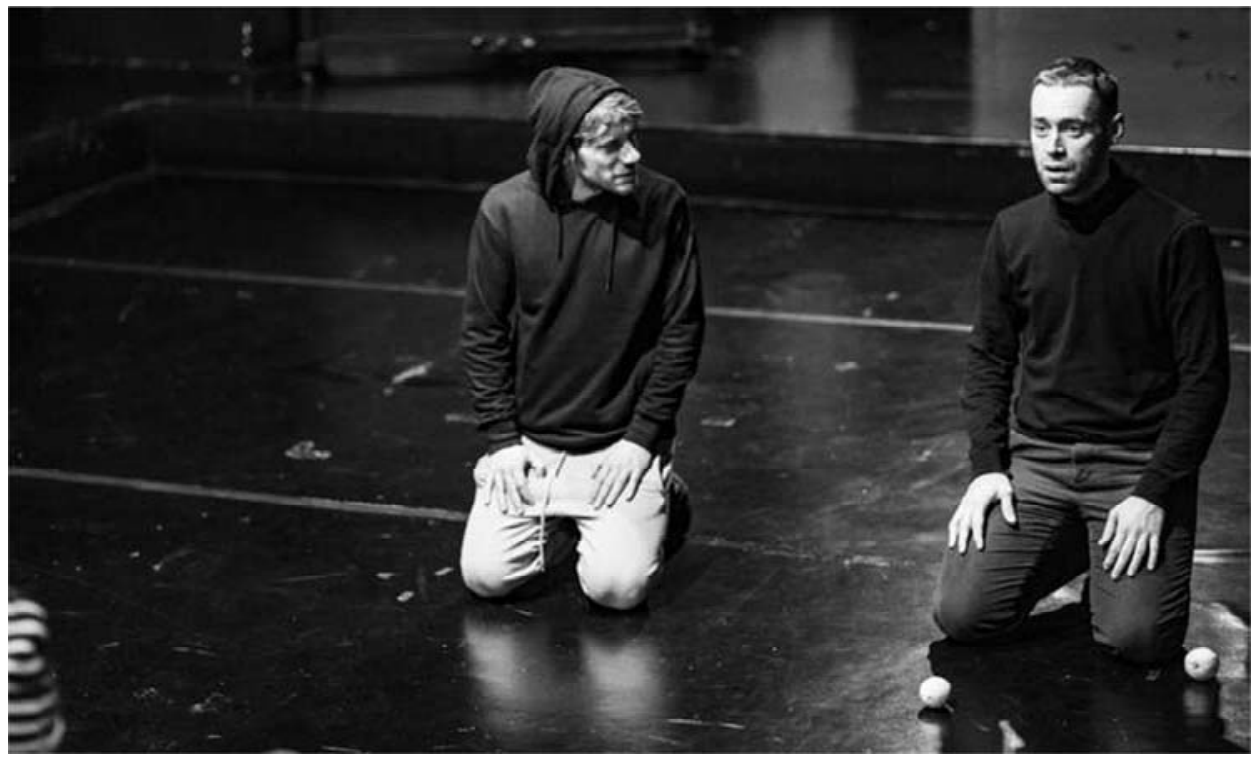

Fot. 1. From left to right: Andreas Kondopoulos as Iago and Giannis Papadopoulos as Othello. Photograph from the rehearsals by Evita Skourleti

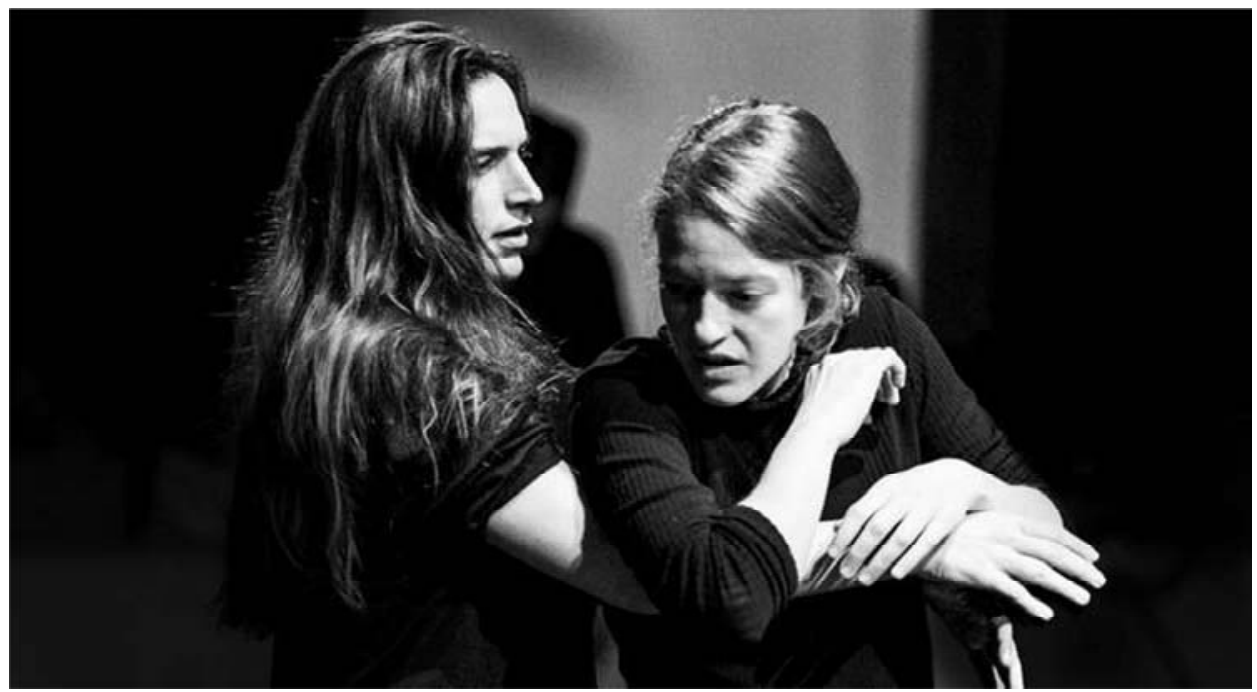

Fot. 2. From left to right: Katerina Louvari-Fassoi as Emilia and Sofia Kokkali as Desdemona. Photograph from the rehearsals by Evita Skourleti 